\title{
JC Virus
}

National Cancer Institute

\section{Source}

National Cancer Institute. JC Virus. NCI Thesaurus. Code C14229.

One of two polyomaviruses found in humans. JC virus can infect the respiratory system, kidneys, or brain, sometimes causing the fatal progressive multifocal leukoencephalopathy in the latter case. It is very widespread with approximately 80 percent of the adult population in the United States having antibodies to and JC. (from WordlQ.com) 